\title{
Animal Husbandry Practices of Livestock Keepers in Mizoram: a Case Study
}

\author{
Lalhmunmawia and Samares Kumar Das*
}

Dept. of Veterinary \& Animal Husbandry Extension, College of Veterinary Sciences \& Animal Husbandry, Central Agricultural University, Selesih, Aizawl, Mizoram (796 015), India

\section{Corresponding Author}

Samares Kumar Das

e-mail: samcau.d1@gmail.com

\author{
Article History \\ Article ID: AR1900 \\ Received in $14^{\text {th }}$ September, 2018 \\ Received in revised form $02^{\text {nd }}$ October, 2018 \\ Accepted in final form $04^{\text {th }}$ October, 2018
}

\begin{abstract}
There is a dearth of literature on animal husbandry practices of Mizoram where people have traditionally been rearing pig and chicken along with subsistence cropping. A case study was conducted in a village of Mizoram to study animal husbandry practices followed by the livestock keepers to help R\&D professionals plan and implement livestock development programs. Case study was done following the principles and methods of Participatory Rural Appraisal (PRA). Study reveals that pig, cattle, chicken, goat and duck were reared in the village. Besides green fodder, cattle were fed wheat flour and wheat bran; pigs were fed home-made feed; chickens were fed broiler ration and rice grain. Cattle and pigs were bred through artificial insemination (Al). Pigs were housed in traditional wooden pigsty. Chicken were sheltered in traditional coop during night, and cattle were sheltered in cattle shed. Villagers were depended on veterinary dispensary for livestock health care. Vaccination and deworming was done regularly in cattle and pig. Milk was sold to Mizoram Multi Commodity Producers Cooperative Union (MULCO) or middlemen. Pigs were slaughtered and sold as pork in the village. Rarely, cattle and chicken were also slaughtered and sold in the village. Eggs were rarely available and sold. Dung was used in bio-gas, or stored and sold as manure in nearby places. There is a scope to improve animal husbandry practices provided remunerative marketing facilities are there.
\end{abstract}

Keywords: Mizoram, animal husbandry, livestock keepers, case study

\section{Introduction}

Livestock plays a significant role in agrarian economy of the country. Share of the agricultural sector in gross domestic product (GDP) has fallen from $37 \%$ in $1980-81$ to $15 \%$ in $2010-$ 11. During this period share of the livestock sector in GDP has increased from $19 \%$ to $27 \%$. Further, the rate of growth of the livestock sector was 1.6 times that of the crop sector and 1.3 times the growth of the whole agricultural sector (Desai, 2014). Mizoram is the fifth smallest state in India with a geographical area of 21,081 sq km inhabited by the people called "Mizo" (Haokip, 2018). The geography of the state is hilly with few plain areas. The state shares its boundary with Manipur, Assam and Tripura. The international boundary comprises the major part of the state border, sharing 404 $\mathrm{km}$ with Myanmar and $318 \mathrm{~km}$ with Bangladesh. According to 2011 Census, Mizoram had a population of 10,91,014 making it the second lowest populous state in the country. The capital (Aizawl) is inhabited by $37 \%$ of the state's total population, making it one with the highest number of people residing in urban areas. Of all the states in the country, it also has the highest tribal population, $94.4 \%$ of the total population (Roluahpuia, 2016). Subsistence agriculture is still dominated by traditional method of shifting cultivation (Jhumming).
Generally, cattle and buffalo are not reared except in wet rice cultivation areas. However, dairy cow is being reared in some villages for milk production. Sheep, goat and pony are rarely found. But poultry and pig in the courtyard and backyard are common (Maithani, 2005; Mondal et al., 2009; Singh, 1994 and 2012). There is a dearth of holistic study on animal husbandry practices followed by the farmers in Mizoram. This calls for a better understanding of livestock farming practices for planning and implementation of location specific research and development programmes in realistic lines. Keeping this in view, a research was undertaken to study livestock farming practices of rural people in Mizoram to suggest R\&D interventions for socio-economic development.

\section{Materials and Methods}

A field study was carried out in a purposively selected village named Muthi in Aizawl district of Mizoram in the month of February 2017. The village was located two-km away from the main road towards Thuampui, and $13 \mathrm{~km}$ from Aizawl city. The condition of the two-km approach road to the village was not good which becomes worse during rainy season. Case study was done following the principles and methods of Participatory Rural Appraisal (PRA). Case study is a method 
of in-depth inquiry of a social unit, i.e. an individual, family, organization, institution, social group or entire community. It allows to retain the meaningful characteristic of real life events with an emphasis on qualitative than quantitative aspects (Yin, 1993). PRA is a group of approaches, methods and behaviours that enable people to express and analyze the realities of their lives and conditions. It provides an alternative method of data collection and analysis with an emphasis on qualitative than quantitative information (Chambers, 1983; Mukherjee, 1993; Pretty, 1995; Reddy, 1999). There are different aspects of rural life not all of which can be measured quantitatively. Some of them can be quantified, some are better described qualitatively while some others remain hidden and elusive. A relative ranking and scoring of issues can enable relative comparisons without absolute measurements (Mukherjee, 1993).Data collected through PRA methods such as listing, narrative, case study, topical interview and observation were analyzed and reported following the principles and methods of PRA.

\section{Results and Discussion}

\subsection{About the village}

Established in 1910, Muthi was a village under Tlangnuam block in Aizawl district of Mizoram. As per 2011 census, the village had a total population of 892 ( 457 male and 435 female) who were Christian by religion. The village was well known for its achievement in football in Mizoram. There were two legends concerning the name of the village. One legend was that the village was named after the "Muthi" tree. Once upon a time, the village was full of Muthi tree. At present there were only a few Muthi tree in the village. Muthi trees were cut down excessively for firewood, furniture, etc. Other legend was that the village got its name from the bird "Murra" (a big eagle) which died on the hill. Once upon a time, there lived two Murra eagles on the hill top migrated from the east. They were male and female. They lived for many years until they died. Consequently, people named the village Muthi, place where eagle died. The village had a primary school established in 1928, a middle school established in 1987 and a high school established in 1996. The village was electrified in 1986. Except rain water harvested during rainy season, springs (Tuikhur) were the main sources of water for the villagers. There were three types of perennial springs: Manapaluituikhur, Sihpuituikhur and Sakhituikhur, and two types of seasonal springs: Lamhnaituikhur and Zokawngtuikur in the village. Perennial springs supplied water round the year, whereas seasonal springs supplied water only during rainy season.

\subsection{Animal husbandry}

It was customary for Mizo to rear one-two pig at the backyard or courtyard. Mizo could not do away with pig. Pig rearing, selling and pork eating was a way of living for Mizo. Muthi was no exception to this. There were a total of 41 families in the village whose main source of income was cattle farming.

\subsubsection{Species and breeds}

Pig, cattle, chicken, goat and duck were found in the village. Pigs were Large White Yorkshire, Hampshire and Landrace cross-bred with local Zovawk. Cattle were Jersey and Holstein Friesian cross-bred. Villagers preferred Holstein Friesian cross as they produced more milk. About 20 years ago, cattle rearing was started for milk production. Chicken was of Desi type which was reared mainly in the backyard. Broiler chicken was also reared by a few villagers on a small-scale basis. Though a few villagers reared duck and goat, it was not so common like pig and cattle. Goats were provided recently to three households under the Tribal Sub-Plan Project (TSPP) of the Central Agricultural University, Imphal implemented by College of Veterinary Sciences \& Animal Husbandry, Selesih. Ducks were reared by only one household in the village.

\subsubsection{A duck farmer}

$\mathrm{Pu}$ Hmuchhuaka was the only villager who was rearing 10 ducks (Varak). Earlier he reared 20-30 ducks. He started rearing ducks three years ago obtaining a pair of male and female ducks from his friend as gift. There was no separate provision for housing ducks. Ducks were sheltered in the dwelling house at night and left loose during day time. Male ducks were sold at ₹ 600 duck $^{-1}$ and female ducks were sold at ₹ 500 duck $^{-1}$. Generally, people from Aizawl came to buy ducks from his doorstep. People believed that duck meat (Varaksa) was good for nerve problems. Sometimes eggs were also sold when it was in abundance at ₹ $10 \mathrm{egg}^{-1}$. There was less hatching during rainy season as compared to other seasons.

\subsubsection{Feeds and feeding}

Animals were reared in the confinement and were stall-fed. Following is a list of feeds and fodder fed to different livestock (Table 1).

Besides green fodder (tree leaf, grass and whole plant), cattle

Table 1: Livestock feeds

\begin{tabular}{ll}
\hline Livestock & Feeds \\
\hline Cattle & $\begin{array}{l}\text { Atta (wheat flour), wheat bran, tree } \\
\text { leaves. }\end{array}$ \\
Pig & Atta, wheat bran, plants, kitchen waste. \\
Chicken (broiler) & Broiler feed mixed with boiled rice. \\
Chicken (Desi) & Rice \\
Duck & Rice, broiler feed, spinach, cabbage. \\
Goat & Tree leaves \\
\hline
\end{tabular}

were also fed wheat flour (Atta) and wheat bran. Generally, water was given trice a day, not ad libitum. Mineral mixture was fed regularly twice a day to pregnant and nursing cattle at about $500 \mathrm{~g}$ per animal at a time, i.e. $1 \mathrm{~kg}$ animal ${ }^{-1}$ day $^{-1}$. Following is a list of tree leaves fed to the cattle (Table 2).

There was no manger in the cattle shed. While fodder was spread on the floor, water and concentrate feeds were given 


\begin{tabular}{|c|c|c|c|}
\hline $\begin{array}{l}\text { SI. } \\
\text { No. }\end{array}$ & Local name & English name & Scientific name \\
\hline 1. & Anku & Eastern nettle tree & Celtis tetrand \\
\hline 2. & Belphuar & Charcoal tree & Trema orientalis \\
\hline 3. & $\begin{array}{l}\text { Hmunphi- } \\
\text { ah }\end{array}$ & Broom leaves & $\begin{array}{l}\text { Thysanolaena } \\
\text { latifolia }\end{array}$ \\
\hline 4. & Hnahkiah & Beauty berry tree & Callicarpa arborea \\
\hline 5. & Khuangthli & Bishop wood & Bischofia javanica \\
\hline 6. & Lamkhuang & Jackfruit & $\begin{array}{l}\text { Artocarpus } \\
\text { heterophyllus }\end{array}$ \\
\hline 7. & Luang & Anderson & $\begin{array}{l}\text { Saccharum } \\
\text { longisetosum }\end{array}$ \\
\hline 8. & Thelret & Rubber tree & Hevea brasiliensis \\
\hline 9. & Thalteh & Kydia & Kydia calycina \\
\hline 10. & Theitat & Monkey fruit & $\begin{array}{l}\text { Artocarpus } \\
\text { lakoocha }\end{array}$ \\
\hline 11. & Theitit & Cluster fig & Ficus prostrata \\
\hline 12. & Thlengreng & Chaster tree & Vitex quunata \\
\hline 13. & Zukbuh & - & $\begin{array}{l}\text { Oreocnide } \\
\text { frutescens }\end{array}$ \\
\hline 14. & Zihnghal & Fragrant Padri tree & $\begin{array}{l}\text { Stereospermum } \\
\text { chelonoides }\end{array}$ \\
\hline 15. & Khupnal & - & Pilea symmeria \\
\hline 16. & Nauthakpui & - & $\begin{array}{l}\text { Litsea } \\
\text { semecarpifolia }\end{array}$ \\
\hline 17. & Balhla & Banana & Musa acuminata \\
\hline 18. & Phan & Vietnam elm & Ulmus lanceifolia \\
\hline 19. & Lehngo & Orange wild rhea & $\begin{array}{l}\text { Debregeasia } \\
\text { longifolia }\end{array}$ \\
\hline 20. & Vau & Orchid tree & Bauhinia variegate \\
\hline 21. & Vakep & $\begin{array}{l}\text { White winged } \\
\text { mussaenda }\end{array}$ & Mussaenda glabra \\
\hline 22. & Chawmzil & Bora bora & $\begin{array}{l}\text { Ligustrum } \\
\text { robustum }\end{array}$ \\
\hline 23. & $\begin{array}{l}\text { Thinghmar- } \\
\text { cha }\end{array}$ & Stink wood & Celtis timorensis \\
\hline
\end{tabular}

in steel or aluminium bucket. Pigs were fed with home-made feed prepared by cooking a combination of kitchen waste and chopped banana stem or green leaves, and kitchen waste and wheat bran or wheat flour. Occasionally, pigs were fed with mineral mixture, calcium and iron preparation, liver tonic, etc. Pregnant sows were fed with mineral mixture twice a day starting from one month before furrowing. Generally, feed and water was given in Chawkuang (wooden trough or trough made of tyre). Following is a list of leaves, roots and parts of the plants fed to pig viz., banana stem and leaf, Japanhlo
(Mikania micrantha), Mau tak (Melocanna baccifera), Vaivakawn par (Tithonia diversifolia), Anhling (Solanum nigrum), Squash (leaf and fruit), Bal (taro)

Broiler chickens were fed with broiler ration purchased from the market mixed with boiled rice twice a day in feeding trough with water provided in water trough. Desi chickens were fed with rice grain twice a day spreading on the ground. Duck feed consists foraging and occasional grain and rice feeding. Goats were provided under the TSPP to three villagers. They had little or no knowledge about goat feeding and other rearing practices.

\subsubsection{Breeding}

Sows were first bred at the age of 9-10 months. Pig owners preferred natural breeding. But, all the boars reared in the village were castrated. So, they got their sows served by the boar reared by a few in Durtlang ₹ 2,000 per service. They also practised artificial insemination ( $\mathrm{Al}$ ) when boar was not available. However, except a few, villagers generally reared male piglet up to the slaughtering age. Cows were first bred at 2-2.5 years of age through artificial insemination (AI), though they preferred natural breeding. Vet or Veterinary Field Assistant (VFA) from Veterinary Dispensary (Durtlang) was called when animals were in heat. The cost of in pig and cattle was ₹ 400 per insemination.Villagers themselves identified a cow in estrus observing the signs like mounting on other animal, swollen vagina, vaginal discharge, frequent urination, restlessness and bellowing. In case of sow, villagers identified an animal in estrus observing the signs like swollen vagina, vaginal discharge and frequent urination.

\subsubsection{A boar farmer}

Pu Isaac of Durtlang was rearing one boar of nine months old. He was also rearing three male piglets (one four months old and two two-and-half months old) to be used for breeding purposes. He started rearing breeding boar four years ago. He used the boar for mating purposes at the age of eight months, and used for two years thereafter. After that the animal was castrated, reared for two-three months, and was slaughtered for selling as meat. Four months ago he slaughtered the boar he was rearing before. He charged ₹ 1,500 per service at Durtlang (at Muthi ₹ 2,000). If it was not successful at first service he would continue free servicing until the animal conceived. In case of Muthi, he charged only for transportation in case of repeat breeding.

\subsubsection{Housing}

\subsubsection{Pig sty}

Pigs were housed in traditional wooden pig sty with tin roof. Earlier thatch was used as roof.

\subsubsection{Coop}

Desichicken was let loose during day and was sheltered at traditional coop (wooden and bamboo) during night. Broiler chicken was sheltered day and night. Broiler was sheltered 
in wood and bamboo made makeshift structure. There was provision made for giving water and feed in bamboo structure hanging at one side.

\subsubsection{Cattle shed}

The cattle shed were mainly constructed with locally available materials like bamboo, woods, etc. beside or little away from the dwelling house as per the convenience.

\subsubsection{Veterinary care}

Vaccination was done regularly in cattle and pig. Vaccination schedule was maintained by the Durtlang Veterinary Dispensary (DVD). Villagers depended solely on the DVD for vaccination. On the scheduled date for vaccination the Village Council President (VCP) would be informed by the dispensary and the VCP would inform the villagers about vaccination of their animals. Pigs were vaccinated against swine fever vaccine and cattle were vaccinated mainly against foot and mouth disease (FMD). Generally, chickens were not vaccinated. Deworming was done in cattle and pigs regularly by the villagers themselves. Pigs were usually dewormed first time at three months age followed by three months interval. Cattle were first dewormed at three months age and then deworming was done as per their convenience generally after 3-4 months interval. They solely depended on the DVD for livestock health services and caring facilities. However, they still possessed and practised some ethno-veterinary practices to treat their animals against the ailments and diseases.

\subsubsection{Marketing}

Pigwas reared for selling live after about one year at $70-80 \mathrm{~kg}$ body weight in the village. Besides, piglet was also sold. The cost of a piglet was $₹ 5,000$. Pork was sold at $₹ 250 \mathrm{~kg}^{-1}$ body weight. So, price of an $80 \mathrm{~kg}$ pig would be of ₹ 20,000 . Live pig was sold based on the heart girth. The heart girth of the pig was measured using a rope. The rope was then folded into halves and its length was measured by holding under the fist. One fist was called one Sum. Since measurement would vary depending on the size of the fist, person having big fist would be chosen to measure the heart girth. Six Sum was equivalent to $45-50$ inches weighing $80-90 \mathrm{~kg}$. Male calf of 5-6 months old was sold at $₹$ 5,000-6,000 calf $^{-1}$. When villagers purchased a male calf from a dairy owner it was reared up to slaughter age to be sold to the butcher coming from nearby place such as Bawngkawn. Generally, chicken reared in the backyard was consumed by the householder. Sometimes, live chicken was sold to the neighbours at ₹ $160 \mathrm{~kg}^{-1}$. Livestock product/ by-product marketing included milk, meat, egg and dung. Dairy owners sold their milk to MULCO or the middlemen in the village. MULCO purchased milk based on fat percentage of milk which varied from $₹ 40$ to $₹ 43 \mathrm{I}^{-1}$. Middlemen purchased milk at a fixed price of ₹ $45 \mathrm{I}^{-1}$. The middlemen sold milk to others at Aizawlat ₹ $60 \mathrm{I}^{-1}$. Mainly pigs were slaughtered in the village by butchers who sold pork on Friday or Saturday morning at ₹ $250 \mathrm{~kg}^{-1}$. Rarely, cattle was also slaughtered and sold in the village $₹ 300 \mathrm{~kg}^{-1}$ beef. Chicken was rarely slaughtered at the village and sold at ₹ $250 \mathrm{~kg}^{-1}$. Eggs were rarely available and sold. Dung was used in bio-gas or stored and sold as manure in nearby place such as Thuampuiat ₹ 250 bag $^{-1}$ (about $40 \mathrm{~kg}$ ).

\subsubsection{A dairy farmer}

The head of the family, PuThanchungnunga, was a 60-year old man with primary education. There were 13 members in his family (four school children, two infants, three adult male and four adult female). There were three earning male members and one earning female member. He was the first man in the village to rear dairy cattle. He had about 30 years of experience in dairy farming. He was a member of the Village Dairy Cooperative Society formed under the auspices of Mizoram Multi Commodity Producers Cooperative Union (MULCO). His main occupation was dairying. He sold milk of about rupees ₹ 12,000 per month from one animal. He sold pig rupees ₹ 20,000 last year. He also earned some from pick-up van hired by the villagers every Friday for transportation of vegetables to Thuampui, Bawngkawn, etc. He had a brick-built dwelling house with a portion traditional Assam type house. Assam house was made of bamboo and wood wall and floor with tin roof. The house was electrified. He possessed a total of six tin (18 bigha) landed property, of which one tin was adjacent to his residence and five tin was away from the residence. In one tin home land he cultivated vegetable (squash, pumpkin, gourd, bean, etc.) mainly for home consumption, except squash. He did not cultivate in 5 tinlands which was utilized by a fellow villager for dairy cattle farming. Except cow dung, he did not receive any rent form that land. Among movable property he had a motor vehicle (Mahindra 407 pick-up van), two refrigerators, one coloured television and one dish TV. He had six cows (five pregnant and one milch), two heifers and two male calves of three months old. Last year he borrowed loan from the UCO bank Thuampui branch for purchasing animals. He had to pay ₹ 7,000 month ${ }^{-1}$ as a premium for the loan. Though considered by the bank as a good customer, he was unable to pay premium for the last two months for which bank employee visited him to enquire about his problem on 20 April 2017. He had a cattle shed of wood and bamboo and a pig sty of wood. Cattle shed were cleaned by sweeping twice a day (morning and afternoon). Occasionally, disinfectant such as potassium permanganate (Tuisen, red water) dissolved in water was used to wash the floor of the shed. All the activities related to dairying (cleaning, milking, feeding, tending, health care, care during pregnancy, parturition, etc.) were done by him and his son. Last year three cows that delivered three calves (one male and two females) died due to prolapse of uterus. Vet from the government dispensary at Durtlang treated the case with ₹ 400. However, animals died after three months of treatment being emaciated. The male calf was sold after five months at ₹ 5,000 to a fellow villager. The female calves were being reared. Animals were fed with green fodder, concentrate and wheat bran regularly. He had to procure green fodder from faraway 
places every Tuesday and Saturday accompanied by one-two labourers ( $₹ 300$ labourer $^{-1}$ ) mainly during December-March when green fodder was scarce in the village. Green fodder was procured from Sairang, Lengte, Lengpui, Khamrang, Serzawl, Lungverh, etc. by pick-up van. During rest of the season mainly rainy season (May-September) green fodder mainly comprised tree leaves obtained from his 5 tinland in the village. Concentrate feed was procured from MULCO at ₹ $1,230 \mathrm{bag}^{-1}(50 \mathrm{~kg})$. Wheat bran was purchased at ₹ 870 bag $^{-1}(40 \mathrm{~kg})$. He purchased concentrate feed $10-12$ bags and wheat bran 6-7 bags month ${ }^{-1}$. He fed $3 \mathrm{~kg}$ concentrate and $1.5 \mathrm{~kg}$ wheat bran milch $^{-1}$ animal day ${ }^{-1}$ divided equally thrice fortified with green fodder, water, salt and mineral mixture. Deworming was done regularly. He got his animals vaccinated at the end of March against FMD free of cost by the VFA from the government dispensary Durtlang. The vet or VFA charged $₹ 400$ as a fee per visit including artificial insemination (AI). A good animal produced $10 \mathrm{lt}$. milk at a time at its peak production (four-six calving). Animal was milked twice a day: morning and afternoon. Thus, he obtained about $20 \mathrm{l}$. milk per day per animal at its peak. He sold his milk to MULCO. MULCO milk van came to the village every morning. Afternoon milk was stored in refrigerator and sold next morning. Based on the solid not fat (SNF) and fat percentage MULCO decided price of the milk which varied between ₹ 40 to ₹ $43 \mathrm{I}^{-1}$. MULCO paid monthly, usually before every $10^{\text {th }}$ day of the month. SNF and fat of the pooled sample was measured by the MULCO to determine the price of the milk. Depending on the feed milk was different in quality. So, poor quality and good quality milk fetched same price. Therefore, he also sold to the middlemen who offered a fixed price $₹ 45 \mathrm{I}^{-1}$. Middleman also paid monthly on the $1^{\text {st }}$ or $2^{\text {nd }}$ day of the month. Milk production was more during May-July and less during February-March. He obtained about one-two bucket full of cow dung per day from each cow. When dung was relatively dry mainly during January-March he stored it for selling as manure at Aizawl, Bawngkawn, Chaltlang, etc. Last year he sold 50 bags of dung manure at ₹ 200 bag $^{-1}$ (40 kg). Cow dung was also used in bio-gas plant every day. Besides, dung was also used to manure the field for vegetable cultivation. He preferred to rear cow up to 8-10 calving (good animal) and 6-7 calving (poor animal). Once, he reared a cow up to 13 calving until its death. When animal became unproductive he sold it to the butcher who frequently visited the village from Durtlang, Bawngkawn, Thuampui, at ₹ 40,000-50,000 thousand animal ${ }^{-1}$ based on the size. He reared male calves up to 5-6 months of age and then sold at ₹ 5,000-6,000 thousand to butcher or fellow villager. After 6-7 calving milk fever, retention of placenta, uterine prolapse started to take place.

\section{Conclusion}

Traditionally pig rearers, villagers fed livestock green fodder, rice grain, wheat flour, wheat bran and kitchen waste. Cattle and pigs were bred artificially. Pigs and chickens were housed in traditional pig sty and coop, respectively. Cattle were sheltered in cattle shed.Villagers were dependent on veterinary dispensary for vaccination and Al. Milk was sold to MULCO or middlemen. Pigs were slaughtered and sold as pork in the village. Rarely, cattle and chicken werealso slaughtered and sold in the village.

\section{References}

Chambers, R., 1983. Rural development: Putting the last first. Pearson Education, New Delhi.

Desai, D.K., 2014. Comments on understanding of livestock. Economic and Political Weekly, 22 ${ }^{\text {nd }}$ March, 68-69.

Haokip, P., 2018. Clans, tribes and unions of tribes: Nomenclature of North East India. Economic and Political Weekly, $1^{\text {st }}$ September, 61-66.

Maithani, B.P., 2005. Shifting cultivation in North-East India: Policy, issues and options. Mittal Publications, New Delhi.

Mondal, S., Vanlalruali, Das, J.K., Tayeng, S., Acharjee, S.K., Halam, J., 2009. The Tradition of Agriculture, Food and Knowledge in North-East India. Agrotech Publishing Academy, Udaipur.

Mukherjee, N., 1993. Participatory rural appraisal: Methodology and applications. Concept Publishing Co., New Delhi.

Pretty, J.N., 1995. Regenerating agriculture: Policies and practice for sustainability and self-reliance. Vikas Publishing House Pvt. Ltd., New Delhi.

Reddy, V.R., 1999. 'Wealth Ranking' in socio-economic research: Substitute or complement? Indian Journal of Agricultural Economics 54(1), 93-103.

Roluahpuia., 2016. Ethnic tension in Mizoram: Contested claims, conflicting positions. Economic and Political Weekly, $16^{\text {th }}$ July, 21-25.

Singh, N.W., 2012. Politics of divine edict and reverse secularism. Economic and Political Weekly, December 29, 23-24.

Singh, S.N., 1994. Mizoram: Historical, geographical, social, economic, political and administrative. Mittal Publications, New Delhi.

Yin, R.K., 1993. Applications of case study research. Applied Social Research Methods Series, Vol 34. Sage Publications, Newbury Park, California. 